\title{
Synergism between Dietary Vitamin $E$ and Exogenous Phytic Acid in Prevention of Warmed-Over Flavour Development in Chicken Breast Meat, Pectoralis major M.
}

\author{
Adriana Lourenço Soares ${ }^{1}$, Rubison Olivo ${ }^{2,3}$, Massami Shimokomaki ${ }^{1,3}$ and Elza Iouko Ida $^{{ }^{*}}$ \\ ${ }^{1}$ Departamento de Tecnologia de Alimentos e Medicamentos; Centro de Ciências Agrárias; Universidade Estadual \\ de Londrina; C. P.6001; 86051-970; Londrina - PR - Brazil. ${ }^{2}$ Globalfood Sistemas, Ingredientes e Tecnologias \\ para Alimentos; São Paulo - SP - Brazil. ${ }^{3}$ Faculdade de Ciências Farmacêuticas; Universidade de São Paulo; São \\ Paulo - SP - Brazil
}

\begin{abstract}
The effect of $\alpha$-tocopheryl acetate (AT) supplementation and exogenous application of this vitamin E associated with phytic acid (PA) on chicken breast meat WOF development was assessed. Control group was fed with 7.7IU of AT/kg of ration and supplemented group was fed with 200.0IU of AT/kg of ration. Dietary vitamin E as measured by TBARS inhibited WOF development by 78.9; 69.0; 60.7 and 46.5\% ( $p<0.05)$ during storage at $6{ }^{\circ} \mathrm{C}$ for $0,1,3$ and 5 days, respectively. This inhibition was significantly increased ( $p<0.05)$ by 86.1; $91.6 ; 92.9$ and $95.3 \%$ during storage at $6^{\circ} \mathrm{C}$ for $0,1,3$ and 5 days, respectively, when $2 \mathrm{mM} P A$ was added in supplemented breast meat. In the exogenous experiment, through Response Surface Methodology design it was found out AT did not have a significant role towards oxidation inhibition whereas $P A$ inhibited partially in samples stored for $48 h$ at $6^{\circ} \mathrm{C}$. The results showed that dietary $A T$ inhibited at initial stage, subsequently $P A$ would act at propagation phase occurring synergetic reaction between both antioxidants.
\end{abstract}

Key words: Warmed over flavour, vitamin E, phytic acid, lipid oxidation inhibition, response surface methodology, breast poultry meat

\section{INTRODUCTION}

Warmed-over flavour has long been recognised as one of the primary causes of quality deterioration during processing as cooling, refrigerating and pre-cooking meat products. The term warmed-over flavour (WOF) was first introduced by Tims and Watts (1958) to describe the rapid development of oxidised flavour in cooked meat upon subsequent heating. The oxidised or stale flavour becomes readily apparent within first $48 \mathrm{hr}$ after refrigerating at $4^{\circ} \mathrm{C}$. The development of WOF is associated with the polyunsaturated fatty acids (PUFA), as phospholipids, located within the cell membranes (Pearson et al., 1977). Meat from different animal species exhibits a greater tendency to develop WOF such as fish > poultry> pork $>$ beef $>$ lamb, in sequence, because of their relative PUFA content. Heating is believed to accelerate the oxidation of phospholipids by liberating catalytically active iron from myoglobin and other iron-containing proteins (Igene et al., 1979).

Phytic acid (PA) is a natural plant constituent, comprising of $1-5 \%$ by weight of legumes, cereals

*Author for correspondence 
or oil seeds. It is a powerful inhibitor of iron-driven hydroxyl radical formation because of its ability to form a unique iron chalete that becomes catalytically inactive (Graf and Eaton, 1990). Vitamin $E$ is a membrane-associated antioxidant and dietary vitamin E supplementation highly suppressed lipid oxidation (Morrissey et al., 1998, O’Neill et al., 1999, Ruiz et al., 1999) and delayed metmyoglobin formation (Jensen et al., 1998, Faustman et al., 1998). It stabilises PUFA and cholesterol in muscle against oxidative deterioration. This effect is primarily due to the incorporation of the vitamin $\mathrm{E}$ into the subcellular membranes, where it maximises the antioxidant capacity (Monahan, et al., 1994; Buckley et al., 1995). It is also believed to suppress the development of Pale, Soft and Exudative (PSE) in chicken breast meat thus improving meat functional properties (Olivo et al., 2001).

The objective of this work was to evaluate the antioxidative activities role of dietary vitamin $\mathrm{E}$ on WOF breast chicken meat and by exogenously application. Moreover, PA was applied exogenously associated with vitamin $\mathrm{E}$ and Response Surface Methodology (RSM) was designed for this experiment.

\section{MATERIALS AND METHODS}

\section{Dietary vitamin $E$ and exogenous phytic acid Chicken and diets}

Commercial hens originated from male Petersen $\mathrm{x}$ female Hubbard $(n=240)$ were raised in two separated groups for 49 days with distinct amounts of AT (BASF) fed throughout their development: 1) Control lot $(n=120)$ consisting of a basal diet of $150.0 \mathrm{IU} / \mathrm{kg}$ of ration from day 1 to day 21,30 IU/kg of ration from day 22 to day 42 and 7.7 IU $/ \mathrm{kg}$ of ration from day 43 to day 49 and 2) Vitamin E supplemented diet lot $(n=120)$ consisting of $150.0 \mathrm{IU} / \mathrm{kg}$ of ration from day 1 to day 21 and $200.0 \mathrm{IU} / \mathrm{kg}$ from day 22 to day 49 . The complete ration formulation and metabolised energy were described in Olivo et al. (2001).

\section{Addition of phytic acid}

Breast meat samples from supplemented diet birds were dipped into $2 \mathrm{mM}$ solution of PA solution (phytic acid dodecassodium salt - Sigma). Three treatments were made: 1) Control group (C), 2) Supplemented group (S) and 3) Supplemented group with exogenous addition of Phytic Acid (S + PA).

\section{WOF development}

Breast meat samples were packed into unsealed pouches and stored at $6^{\circ} \mathrm{C}$ for 5 days. Samples from $0,1,3$ and 5 days were vacuum packed and cooked in a water bath up to an internal temperature of $75^{\circ} \mathrm{C}$. Subsequently, unsealed packaged samples were stored at $6^{\circ} \mathrm{C}$ for $48 \mathrm{~h}$ under fluorescent light (400 lux). Then, samples were re-heated in a microwave (High Power level, Panasonic) for 4 minutes, cooled to room temperature and development of WOF was determined by thiobarbituric acid (TBARS) measurement following the technique described by Tarladgis et al. (1964).

\section{Determination of Vitamin E}

$\alpha$-Tocopherol concentration in Pectoralis rigor muscle was determined by HPLC (Shimadzu, model LC-10AD) following the methodology described by Liu et al. (1996).

\section{Statistical analysis}

Data were analysed by ANOVA using the SAS (Statistical Analysis System). The main effects in analysis were treatments (Control group, Supplemented group and Supplemented group with exogenous addition of PA) without interaction. Tukey`s multiple range tests were used to determine significant difference $(\mathrm{p}<0.05)$ among groups.

\section{Exogenous vitamin $E$ and phytic acid Experimental design}

A 3-level-2-factor experimental design with three replicate at the center point was adopted. The variables and levels in terms of coded and uncoded are given in Table 1. Assays were conducted with addition of PA $(0-4 \mathrm{mM})$ and AT (Roche) $(0-0.40 \mathrm{~g} / \mathrm{kg}$ of samples) in fresh breast meat samples according to experimental design (Table 1).

Samples were vacuum packed and cooked in a water bath to an internal temperature of $75^{\circ} \mathrm{C}$. Subsequently, unsealed packed samples were stored at $6^{\circ} \mathrm{C}$ for $48 \mathrm{~h}$ under fluorescent light $(400$ lux). Then, samples were re-heated in a microwave for 4 minutes, cooled to room temperature and development of WOF was monitored by TBARS measurement (Tarladgis et al., 1964).

The response function was WOF development which was transformed into logarithmic to the base 10 to assure the normality and expressed in 
$\log$ of $\mu \mathrm{g}$ TBARS $/ \mathrm{kg}$ of samples (Box and Draper, 1987). The analysis of variance and regression were performed using the SAS (Statistical Analysis Systems) and graphics were plotted in Statistica software (Oklahoma, USA, 1996).

Table 1 - Experimental design with coded and uncoded variables and levels

\begin{tabular}{|c|c|c|c|c|}
\hline \multirow[t]{2}{*}{ Assay $^{*}$} & \multicolumn{2}{|c|}{ Coded variables } & \multicolumn{2}{|c|}{ Uncoded variables } \\
\hline & $\mathbf{x}_{1}$ & $\mathbf{x}_{2}$ & $\mathrm{X}_{1}$ & $\mathbf{X}_{2}$ \\
\hline 1 & -1 & -1 & 0 & 0 \\
\hline 2 & 0 & -1 & 2 & 0 \\
\hline 3 & +1 & -1 & 4 & 0 \\
\hline 4 & -1 & 0 & 0 & 0.20 \\
\hline 5 & 0 & 0 & 2 & 0.20 \\
\hline 6 & 0 & 0 & 2 & 0.20 \\
\hline 7 & 0 & 0 & 2 & 0.20 \\
\hline 8 & +1 & 0 & 4 & 0.20 \\
\hline 9 & -1 & +1 & 0 & 0.40 \\
\hline 10 & 0 & +1 & 2 & 0.40 \\
\hline 11 & +1 & +1 & 4 & 0.40 \\
\hline
\end{tabular}

$\overline{\mathrm{X}_{1}=\text { phytic acid }(\mathrm{mM}) \text { and } \mathrm{X}_{2}=\text { vitamin } \mathrm{E}(\mathrm{g} \text { of tocopheryl }}$ acetate / $\mathrm{kg}$ of samples)

* Assays were run in a random order

\section{RESULTS AND DISCUSSION}

\section{Dietary vitamin $E$ and exogenous phytic acid}

Table 2 shows AT concentrations in fresh and cooked chicken Pectoralis major. Dietary vitamin $\mathrm{E}$ supplementation increased AT concentration by 2-3 fold ( $\mathrm{p}<0.05$ ) in breast meat than control group (C). No significant difference $(p<0.05)$ was observed between fresh and cooked meat in AT concentration. Thus, heating treatment did not affect the AT intramuscular concentration. Similar results were reported for cooked beef by Liu et al. (1994).

Table 2 - Vitamin E concentration in breast chicken meat, Pectoralis major, fed with vitamin E supplemented diet

\begin{tabular}{cc}
\hline Treatments & $\begin{array}{c}\boldsymbol{\alpha} \text {-tocopherol concentrations } \\
(\boldsymbol{\mu g} / \mathbf{g})\end{array}$ \\
\hline C & $10.52^{\mathrm{b}} \pm 1.09$ \\
S & $29.31^{\mathrm{a}} \pm 5.97$ \\
S + PA & $30.03^{\mathrm{a}} \pm 3.17$ \\
S cooked & $29.03^{\mathrm{a}} \pm 1.57$
\end{tabular}

Values represent means of three samples \pm standard error. Means with different superscripts are significantly different $(\mathrm{p}<0.05)$ by test Tukey

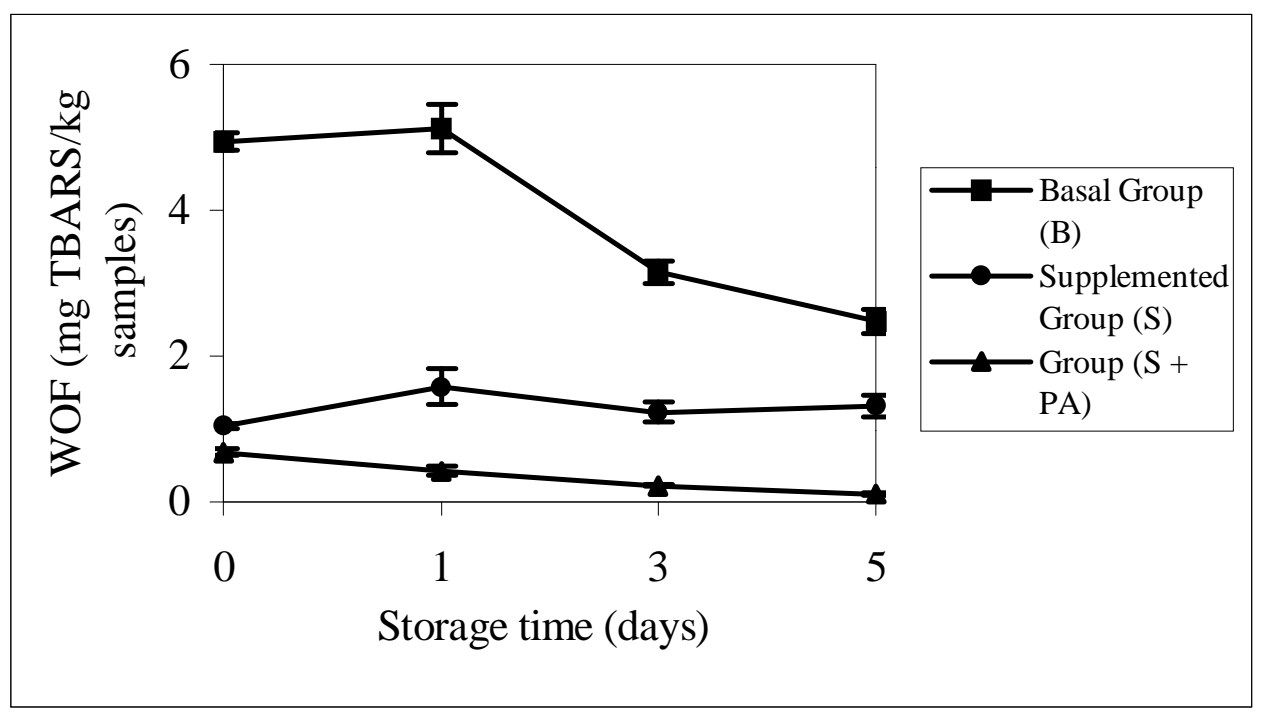

Figure 1 - Effect of dietary vitamin E supplementation and exogenous phytic acid on WOF development of breast chicken meat Pectoralis major stored at $6^{\circ} \mathrm{C}$ for 5 days 
Fig. 1 represents TBARS values of cooked meat from control group (C) which decreased after 5th day of storage from 4.941 (0 day) to $2.477 \mathrm{mg} / \mathrm{kg}$ of sample and conversely TBARS values of cooked meat from supplemented group (S), 1.043 (0 day) to $1.324 \mathrm{mg} / \mathrm{kg}$ of sample at 5 th day of storage. When PA was added in supplemented samples $(\mathrm{S}+\mathrm{PA})$, TBARS values decreased from 0.658 (0 day) to $0.116 \mathrm{mg} / \mathrm{kg}$ of sample after 5 th day of storage.

Dietary vitamin E supplementation inhibited WOF development by $78.9 ; 69.0 ; 60.7(\mathrm{p}<0.05)$ and $46.5 \%$ during storage for $0,1,3$ and 5 days, respectively. This inhibition was significantly increased $(p<0.05)$ by $86.1 ; 91.6 ; 92.9$ and $95.3 \%$ during storage for $0,1,3$ and 5 days, respectively, when $2 \mathrm{mM}$ PA was added in supplemented breast meat. These results apparently due to the presence of vitamin $\mathrm{E}$ through its cromanol ring position which were could be located at the cell membranes phospholipids polar portion leaving out its phytol chain to interact with unsaturated fatty acid chain offering protection against oxidation reaction. This fact was probably the initial step for avoiding lipid oxidation development (Schaeffer et al., 1995).

PA by its chelating properties would sequester iron ions and synergistically stops chemically the major WOF development.

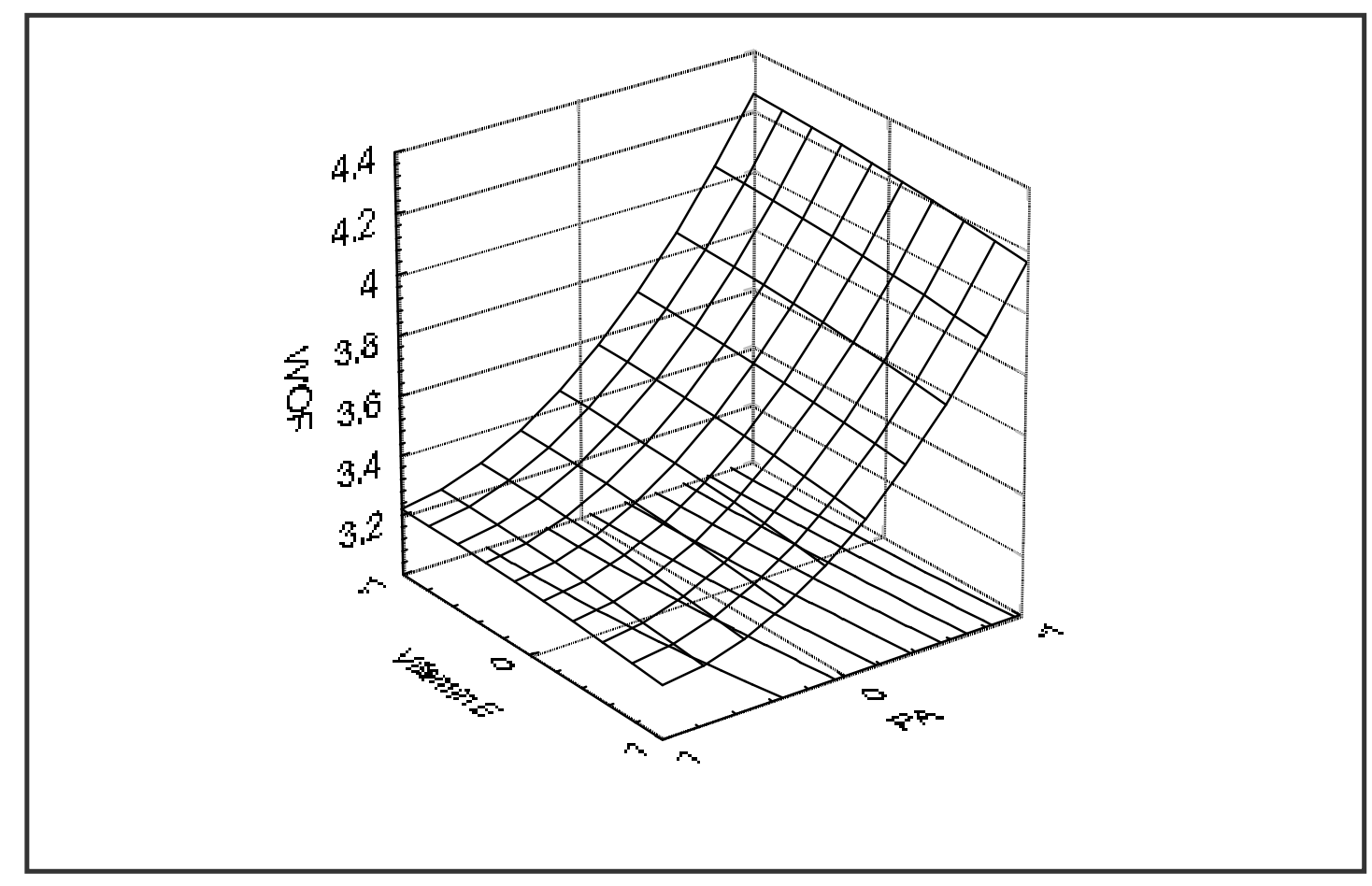

Figure 2 - Effect of vitamin E and phytic acid concentrations on WOF development of breast chicken meat Pectoralis major stored at $6^{\circ} \mathrm{C}$ for 48 hours

\section{Exogenous vitamin $E$ and phytic acid}

The analysis of variance for WOF development is shown in Table 3. The model for WOF development presented satisfactory $R^{2}$ (0.977), coefficient of variation of $2.50 \%$, indicating low variability of results and regression highly significant $(\mathrm{P}=0.0004)$. However, the lack of fit was significant $(\mathrm{P}=0.0277)$ and as pointed out by
Box and Draper (1987), this condition would not be considered when sum of square of pure error very low (Table 3 ). Thus, the model was could be consider to be adequate for the present investigation:

$\mathrm{Y}=3.485-0.505 \mathrm{x}_{1}-0.034 \mathrm{x}_{2}+0.232 \mathrm{x}_{1}^{2}-0.012 \mathrm{x}_{2}{ }^{2}+$ $0.012 \mathrm{x}_{1} \mathrm{x}_{2}$ 
1Table 3 - Analysis of variance for WOF development

\begin{tabular}{c|c|c|c}
\hline Source & df & Sum of square & Prob $>$ F \\
\hline Model & 5 & 1.6825 & 0.0004 \\
Linear & 2 & 1.5391 & 0.0001 \\
Quadratic & 2 & 0.1428 & 0.0229 \\
Cross product & 1 & 0.0006 & 0.8020 \\
Lack of fit & 3 & 0.0397 & 0.0277 \\
Pure error & 2 & 0.0008 & \\
Total error & 5 & 0.0405 & \\
$\mathrm{R}^{2}=0.977 ;$ cv $=2.50 \%$ &
\end{tabular}

The relationship between factors and WOF development could be better understood by examining the three dimensional and contour plots according to RSM design in Fig. 2. Only the presence of phytic acid showed to be significantly relevant. The exogenous addition of vitamin $\mathrm{E}$ up to $0.40 \mathrm{~g} / \mathrm{kg}$ of sample did not affect WOF formation. Dietary supplementation with vitamin E efficiently inhibited WOF development (Shimokomaki et al., 1999) and also the dietary vitamin E supplementation highly suppressed lipid oxidation and delayed metmyoglobin formation. It stabilises polyunsaturated fatty acids and cholesterol molecules in muscle against oxidative deterioration. This effect is primarily due to the incorporation of the vitamin $\mathrm{E}$ into subcellular membranes, where it maximises the antioxidant capacity (Buckley et al., 1995). In our study, the exogenous vitamin $\mathrm{E}$ did not become an integral part of membrane, and consequently was not as effective as dietary incorporated vitamin $\mathrm{E}$.

\section{CONCLUSIONS}

Poultry vitamin E dietary supplementation retarded WOF development at initial stage in chicken breast meat by avoiding free radicals formation. Phytic acid (PA) inhibited it subsequently by sequestering catalytically active iron mostly from myoglobin at propagation stage in a synergetic effect between both natural antioxidants. This phenomenon was not observed when Vitamin E and PA were added exogenously into meat samples.

\section{ACKNOWLEDGEMENTS}

ALS is under CAPES scholarship. EII and MS are CNPq Research Fellows. This project was partially supported by CNPq Proc. 521047/96-0.

\section{RESUMO}

$O$ efeito da suplementação de acetato $\alpha$-tocoferol (AT) e a aplicação exógena desta vitamina $\mathrm{E}$ associada com ácido fítico (AP) foi avaliado no desenvolvimento do WOF em filé de peito de frango. $\mathrm{O}$ grupo controle foi alimentado com 7,7IU de AT/kg de ração e o grupo suplementado foi alimentado com $200 \mathrm{IU}$ de AT/kg de ração. A vitamina $\mathrm{E}$ na dieta inibiu o desenvolvimento de WOF, medido através do TBARS, em 78,9; 69,0; 60,7 e $46,5 \%(p<0,05)$ durante armazenamento a $6^{\circ} \mathrm{C}$ durante $0,1,3$ e 5 dias respectivamente. Esta inibição foi significativamente aumentada $(p<0,05)$ em 86,$1 ; \quad 91,6 ; \quad 92,9$ e $95,3 \%$ armazenamento a $6^{\circ} \mathrm{C}$ durante $0,1,3$ e 5 dias respectivamente, quando $2 \mathrm{mM}$ de $\mathrm{PA}$ foi adicionado no filé de peito de frango suplementado. Através da Metodologia de Superfície de Resposta, no experimento exógeno, foi observado que o AT parece não ter um papel significante em relação à inibição da oxidação, enquanto que AP inibe parcialmente nas amostras armazenadas a $6^{\circ} \mathrm{C}$ durante $48 \mathrm{~h}$. Esses resultados mostram que AT na dieta inibiria na iniciação e subseqüentemente AP atuaria na propagação, ocorrendo uma reação sinérgica entre os dois antioxidantes.

\section{REFERENCES}

Box, G. E. P. and Draper, N. E. (1987), Empirical model building and response surfaces. $3^{\text {rd }}$ ed. John Wiley and Sons, New York, USA.

Buckley, D. J.; Morrissey, P. A. and Gray, J. I. (1995), Influence of dietary vitamin $\mathrm{E}$ on the oxidative stability and quality of pig meat. J. Anim. Sci., 73, 3122-3130.

Faustman, C.; Chan, W. K. M.; Schaffer, D. M. and Havens, A. (1998), Beef colour update: The role for vitamin E. J. Anim. Sci., 76, 1019-1026.

Graf, E and Eaton, J. W. (1990), Antioxidant functions of phytic acid. Free Radical Biology and Medicine, 8, 61-69. 
Igene, J. O.; King, J. A.; Pearson, A. M. and Gray, J. I. (1979), Influence of heme pigments, nitrite and non-heme iron on development of warmed-over flavour (WOF) in cooked meat. J. Agric. Food Chem., 27, 838-842.

Jensen, C.; Lauridsen, C. and Bertelsen, G. (1998), Dietary vitamin E: quality and storage stability of pork and poultry. Trends Food Sci. Technol., 9, 62-72.

Liu, Q.; Scheller, D. M.; Arp, S. C. and Williams, S. N. (1994), Dietary $\alpha$-tocopheryl acetate contributes to lipid stability in cooked beef. J. Food Sci., 59, 288-290.

Liu, Q.; Scheller, K. and Schaffer, D. M. (1996), Technical note: a simplified procedure of vitamin $\mathrm{E}$ determination in beef muscle. J. Anim. Sci., 74, 106-116.

Monahan, F. J.; Asghar, A.; Gray, J. I.; Buckely, D. J. and Morrissey, P. A. (1994), Effect of oxidized dietary lipid and vitamin $\mathrm{E}$ on the colour stability of pork chops. Meat Sci., 37, 205-215.

Morrissey, P. A.; Sheehy, P. J. A.; Galvin, K.; Kerry, J. and Buckley, D. J. (1998), Lipid stability in meat and meat products. Meat Sci., 49, 73S-86S.

Olivo, R.; Soares, A. L.; Ida, E. I. and Shimokomaki, M. (2001), Dietary Vitamin E inhibits poultry PSE and improves meat functional properties. J. Food Biochem., 25, 271-283.

O'Neill, L. M.; Galvin, K.; Morrissey, P. A. and Buckley, D. J. (1999), Effect of carnosine, salt and dietary vitamin $\mathrm{E}$ on the oxidative stability of chicken meat. Meat Sci., 52, 89-94.

Pearson, A. M.; Love, J. D. and Shortland, F. B. (1977), "Warmed-over" flavor in meat, poultry, and fish. Adv. Food Res., 23, 1-74.

Ruiz, J. A.; Pérez-Vendrell, A. M. and Esteve-García, E. (1999), Effect of $\beta$-carotene and vitamin $\mathrm{E}$ on oxidative stability in leg meat of broilers fed supplemental fats. J. Agric. Food Chem., 47, 448-454.

SAS Institute (1989), SAS/STAT. Guide for personal computers. $6^{\text {th }}$ ed. The Institute: Cary, NC.

Schaeffer, D. M.; Liu, Q.; Faustman, C.; Yin, M. C. (1995), Supranutritional administration of vitamins E and $\mathrm{C}$ improves oxidative stability of beef. J. Nutrition, 125, 1792S-1798S.
Shimokomaki, M.; Soares, A. L.; Ida, E. I. and Olivo, R. (1999), Synergism between dietary vitamin $\mathrm{E}$ and exogenous phytic acid in prevention of warmed-over flavor in chicken Pectoralis major. In: Proceedings of the 1999 IFT Annual Meeting. Chicago : IFT. pp. 184.

Tarladgis, B. G.; Pearson, A. M. and Dugan, R. (1964), Chemistry of the 2-thiobarbituric acid test for determination of oxidative rancidity in foods. II- Formation of the TBA-malonaldehyde complex without acid-heat treatment. J. Food Sci. Agric., 5, 602-604.

Tims, M. J. and Watts, B. M. (1958), Protection of cooked meats with phosphates. Food Technol., 12, 240-243.
Received: March 01, 2002; Revised: January 09, 2003; Accepted: April 28, 2003. 